\title{
中国人の訪日旅行の形態とその变化
}

一観光からッーリズムへ一

\section{Changes in the Patterns of Chinese Tourism to Japan}

\author{
清水 伊織* \\ Iori SHIMIZU*
}

キーワード：中国人旅行者, 訪日旅行, 観光, 商用旅行, 修学旅行

Key words : Chinese tourists, visit to Japan, sightseeing tour, business trip, school excursion

\section{I ．はじめに}

近年のグローバリゼーションの進展により， 国際的な人の移動はよりいっそう活発化しつつ ある。2000年に世界全体で 6 億 8700 万人を記録し た海外旅行者数は, 今後も加速度的に増加を続 けていくと予想されている。そのなかでも，海外 に出かける中国人旅行者数の急激な増加は注目に 值する。2004年の香港・マカオへの旅行を含む中

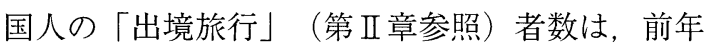
比で $42.7 \%$ 増加し， 2,885万 2,900 人を記録した。 また, 中国人の海外旅行目的地として解禁されて いる国・地域も全世界に拡大傾向にあり, 現在で は86の国・地域が対象となっている。こうしたな か, 中国人旅行者は，その市場の潜在性や滞在先 での消費金額の大きさなどから，旅行者を受け入 れる側の国・地域からも大きな注目を集めてい る。つまり，これまで世界有数の旅行者受け入れ 国であった中国は，現在では旅行者送り出し国の 一つとしても重要視されるようになっているので ある。

一方, 日本の側から中国人旅行者を見た場合に は，次のようなことが言える。日本は海外への旅 行者送り出しに比べ, 外国人旅行者の受け入れが 極端に少なく，国際観光収支の不均衡を是正する ことは日本政府の政策的な課題の一つとして認識 されている。こうしたなか, 「ウェルカムプラン 21 (訪日観光交流倍増計画) 」（1995年）や「ビ
ジット・ジャパン・キャンペーン」（2003年〜） など，訪日外国人旅行者の増加を目指す政策が策 定されている。

訪日外国人旅行者数を国・地域別にみると， 特に増加が著しいのが, 韓国・台湾・中国など, 東アジア地域からの旅行者であり（図1），その シェアや伸び率から見ても，東アジア地域の旅 行者をいかに取り込むかが重要な課題となって いる。特に, 中国人旅行者は今後の市場拡大を考 慮した場合に, 最も重要な誘致対象となる。さら に，こうした国家レベルでの対応とは別に，近年 では，日本の各自治体においても，中国の各自治 体と地域的な交流を行い, 地域レベルで中国人旅 行者を積極的に誘致しようとする動きがみられる ようになっている。

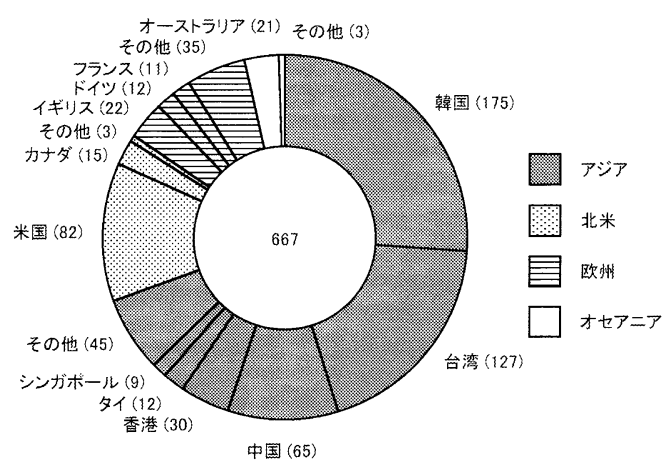

図 1 州別，国・地域別訪日外国人旅行者数の割合(単位：万人) 資料：国土交通省（2006）をもとに作成。

*トップッアー株式会社

*Toptour Corporation 
本稿が注目するのは，日本の旅行会社や自治 体の中国人訪日旅行をめぐる誘致活動の, ここ数 年間における変化である。2000年 9 月に中国の一 部地域で, 訪日団体観光旅行が解禁されたこと によって, 日本でも，中国人観光客が誘致活動の 対象として認識されるようになった。日本の中国 人訪日旅行への対応は, いわゆる「観光旅行」の 促進を, その中心的な課題としてきたが, 観光客 増加への期待とは裏腹に, 各種の規制が観光客誘 致の障壁として存在しているのも事実である。こ うしたなか, 日本の旅行業界や一部の自治体のあ いだでは，「観光客」以外の中国人旅行者に注目 しようとする動きがみられるようになってきた。 たとえば，旅行会社のなかには，中国人旅行者に 注目しつつも，「観光旅行」は扱わず，「商用旅 行」のみを扱う会社も少なくない。また, 中国人 旅行者の増加を目論む自治体も, 単なる「観光」 ではなく, 中国からの修学旅行の誘致に積極的な 姿勢を見せはじめている。つまり, 日本政府の推 進するビジット・ジャパン・キャンペーン（以 下, VJCと略記) などによって, 外国人の訪日観 光客数の増加が期待されている一方で, 実際に 旅行者を受け入れる自治体や旅行業界のあいだで は,「観光以外」の旅行者に注目するという状況 が生まれているのである。

日本を訪れる旅行者が「観光客」であるか否か は，受け入れ側にとってどのような意味を持ちう るのか。この点を理解しないと, 中国人の訪日旅 行をめぐる現在の状況を正しく認識することはで きない。以上のことから, 本稿の目的は次のよう

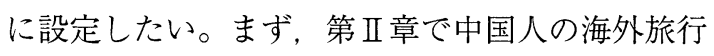
について概観した上で, 第正章で, 訪日旅行の現 状について「団体観光旅行」を中心に検討する。 第IV 章では, 2004年から2005年にかけて行った聞 き取り調査と, 2006年に行った聞き取り調査の比 較から，日本の旅行会社と自治体の中国人訪日旅 行に対する取り組みの変化について考察する。さ らに，第 $\mathrm{V}$ 章で旅行会社や自治体の中で観光旅行 から商用旅行や修学旅行などへ関心が移行しつつ あるという点をもとに，日本のツーリズムのあり 方と関連付けながら,「観光」概念の再検討の必 要性を指摘する。

\section{II. 中国人海外旅行}

\section{1.中国人の「出境旅行」とは何か}

中国人の「出境旅行」は，「香港・マカオ・台 湾以外に住む中国国民が, 香港・マカオを含む外 国へ行く旅行」と定義される。そして，この「出 境旅行」は，「香港・マカオ旅行」，「国境旅 行」,「海外旅行」1) の3つに大別される（国家 旅游局, 1997）。ここでは, 考察の前提として, 中国人の「出境旅行」について概説を行ったうえ で，とくに「海外旅行」の現状について，制度的 な面からの考察を行う。

\section{（1）香港・マカオ旅行}

「香港・マカオ旅行」は, 広東省, 福建省な どに住む中国人の親族訪問から発展してきたもの

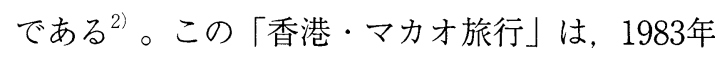
11月15日に, 広東省の旅行会社が広東省の住民を 対象として, 香港・マカオ地区の親族を訪問する ための「香港・マカオ親族訪問ツアー」を設定し たのが最初である。ただし，訪問先に居住する親 族が香港での旅行費用を負担することが条件とさ れ, ツアーの参加人数も限定された。

その後1992年には, 中国国務院が, 福建省の海 外旅行会社による香港・マカオ親族訪問旅行等を 認可し, これを契機として香港・マカオ親族訪問 旅行が中国全土で解禁された。1996年には毎日平 均で 900 人以上, 年間 30 万人以上の中国人が本土 から香港・マカオを訪れるようになっている。

現在では, 中国各地38都市からの個人旅行が解 禁され, 香港・マカオへの旅行者数は毎年大きな 割合で増加し続けている。中国人の「出境旅行」 において初めて個人旅行が解禁されたことで, 今 後, 個人志向の旅行が増加し, 旅行形態の多様化 も進行することが予想される。

\section{（2）国境旅行}

「国境旅行」とは，「指定された旅行会社の手 配により，中国国民及び隣接する国の国民が，グ ループで指定された国境のゲートから出入国をす るもので, 双方の政府の決定した区域と期限内で 行う旅行」とされる ${ }^{3)}$ (国家旅游局, 1997）。

「国境旅行」の手続きは次節で説明する「海外 旅行」よりも簡便で, 中国人の「国境旅行」参加 
者は, 通常のパスポートの代わりに, 「出入国通 行証明書」を提出することで出国が可能となる。 また，「海外旅行」と比較して費用が廉価で，沿 岸部より平均所得が低い内陸部の省からも旅行者 を集めている。

これらの旅行者の旅行目的としては，観光の ほかに，買い物，国境貿易などが挙げられるが，

「国境旅行」が行われる地域によって, 旅行の特 徴に大きな違いがみられる。鐘・郭（2001）によ れば，北朝鮮への「国境旅行」は，その目的は観 光が多くを占め, ベトナム・ラオス・ミャンマー など東南アジアへの「国境流行」は，観光のほか に買い物も主要な目的となっている。これらの

「国境旅行」における旅行者の流動は中国から隣 国へと向かう流れが主で，国境地帯に住む中国人 の経済発展や，少数民族との交流を促進するため に存在しているという側面が強い。

一方，ロシア ${ }^{4)}$ との国境では，主に買い物や貿 易が行われ，旅行者の流動は双方向的である。近 年では，ロシアから中国を訪れる旅行者が増加す るなど，従来の「国境旅行」とは異なる状況も呈 している。

\section{（3）海外旅行}

中国人の「海外旅行」は，「香港・マカオ旅 行」や「国境旅行」から少し遅れて認められた 旅行方式である。この旅行形態は，査証の種類に よって, 観光旅行, 商用旅行, 親族訪問旅行など に下位分類される。

観光を目的とした「海外旅行」については， 香港・マカオやヨーロッパの一部地域を除いて, 団体旅行の形式しか認められていない。また， 渡航先は，旅行者が自由に選択できるわけでは なく，「海外旅行目的地 (Approved Destination Status：ADS）」として中国政府の承認を受けた 国・地域に限られる5)。

この「海外旅行」の認可の経緯は, 以下の通り である。1990年10月，中国国家旅游局などが「我 が国国民の東南アジア三ヶ国観光に関する管理条 例」を発表し、シンガポール・マレーシア・タイ の 3 ケ国に個人旅行をすることが認められた。当 時の海外旅行では，管理条例の適用は親族訪問旅 行のみに限られており，海外の親族が旅行者の保
証人となることや，海外で発生する旅行費用を支 払うことなどが規定されていた。つまり，東南ア ジアに親族を持たない中国人は，旅行すること自 体が認められていなかったのである。また，「海 外旅行」者数は中国政府によって管理されてい たため，海外旅行の経営認可を受けていた旅行会 社は旅行の参加者数を一定限度以上に増やすこと ができず，無許可で海外旅行業務を行う会社も現 れた。このため, 海外旅行市場の整備を目的とし て，1997年 3 月には，国家旅游局と公安部によっ て「中国人海外自費旅行管理に関する暫定条例」 が発表された。この条例によって，旅行会社の海 外旅行業務に対する管理が強化され, 同時に, 海 外旅行市場の整備も本格的に進められた ${ }^{6)}$ 。

なお，2007年 1 月 1 日現在，中国政府によって 「海外旅行」の目的地として認められている国 地域は86である。

\section{2. 観光目的の「海外旅行」}

国家旅游局によれば，2004年の中国人「出境 旅行」者数は 2,885 万 2,900 人を記録し，前年よ り42.7\%増加している。1994年が373万 3,600 人で あったので，過去10年間で旅行者数が約 7.7 倍に 増加したことになる。このように短期間で旅行者 数が大きく増加した背景には，私用による「出境 旅行」者数の急増がある（図 2 ）。「公用」旅券 による旅行は，一般的に政府による派遣・研修が 中心であるが，私用の「出境旅行」は，「私用」 旅券を利用するもので, 海外での長期滞在, 親族 訪問，自費留学，観光等を主な目的としている。

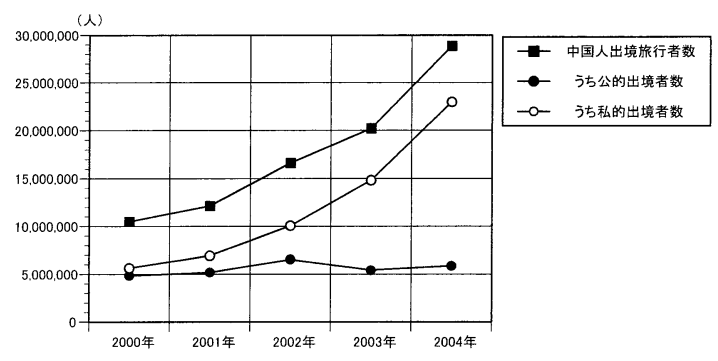

図2 中国人出境旅行者数

資料：国家旅游局 (2001 2005)をもとに作成。

ここでは，中国人の「出境旅行」のうち，私 用の「海外旅行」，とくに観光目的の旅行につい 
て検討したい。中国人の「海外旅行」は, 商用旅 行や親族訪問旅行などに関しては，個人の手配に よって個人旅行を行うことができる。一方，観光 目的の旅行に関しては, 香港・マカオやヨーロッ パなど一部の地域を除いて, 旅行会社のツアーに よる団体旅行のみが認められている。

これまで，中国人のツアーは，中国語で「走 馬観花」（馬に乗って花見をする意）と形容さ れるような, 一度の旅行で多くの観光地をまわ るツアーが主流であった。同じ価格であれば，訪 問地が多いほど旅行者に歓迎されるという傾向も みられた。しかし近年では，そうしたツアーに加 えて，これまでとは異なった特徵を持つッアーも 実施されている。たとえば，1つの都市に長期間 逗留する滞在型のツアーが増えてきたことが挙げ られるほか, チャーター機で国外の地方都市を直 接訪れる旅行や, 東南アジアのリゾート地で長期 休暇を過ごすッアーも提供されつつある。ッアー の内容も多様化している。たとえば，2006年10月 の国慶節の休暇期間には，川端康成が著した小説 「雪国」をテーマとして, 新潟県の越後湯沢温泉 を訪れるッアーが販売された。

このほか, 中国語で「自由行」といわれるッ アーも, 近年多く行われている。「自由行」と は，個人旅行が認められている香港・マカオや ヨーロッパの一部の地域へ, 旅行会社のパッケー ジ・ツアーを利用して個人で旅行する形式であ る。2006年11月27日の北京娛楽信報によれば, 12月に北京市の旅行会社各社が販売するッアー では，ヨーロッパと香港への「自由行」が旅行 者の関心を集めているという。「自由行」のツ アーの最低価格は, ヨーロッパ方面へのッアーで 4,699元（約 7 万円），香港へのッアーで約 1,000 元（約 1 万 5,000 円）となっている ${ }^{7)}$ 。この価格 は，一般の団体旅行のッアーと同程度の価格であ るため，旅程に拘束される団体旅行に比べて人気 が高く，「自由行」の形式を選ぶ旅行者も増える 傾向にある。

しかし，日本を含む多くの国・地域に扔いて は，いまだに観光旅行中の自由行動が原則として 認められていない。その背景には, 外貨流出や旅 行者の逃亡などの問題がある。

国家旅游局の観光振興に対する基本的な方針
は, 「外国人旅行者の訪中旅行は強力に, 中国人 の国内旅行は積極的に, 中国人の出境旅行に関し ては適度に推進する」というものである。1978年 から中国政府が改革・開放政策を採用し, 経済発 展のための外貨獲得手段のひとつとして観光業が 重視されるようになった。一方，中国人の「海外 旅行」に関しては, 外貨流出, 滞在先での逃亡. 不法滞在などの問題が背景にあり，1979年まで一 般の中国人に対しては認められていなかった。し かし, 対外開放政策を契機に, 政府や企業の経済 活動や文化交流なども盛んになり，それらを目的 とした海外出張が徐々に認められるようになって いった。こうした状況のなかで，私用の「海外旅 行」への規制も緩和されるようになってきた。

ただし，「海外旅行」に関する規制が全体的に 緩和され，取扱認可を受ける旅行会社も増加する 一方で，逆に旅行会社に対する管理は強められつ つある。これは, 旅行会社数の急激な増加によっ て，旅行ツアーの価格競争が激化し，悪質なツ アーを実施する旅行会社が増加していることが主 な要因となっている。国家旅游局は, 旅行会社の 違反に対する罰則を強化する一方で，誠実で信用 できるツアーを実施する会社を「誠信旅行社」と して認定するなどの対策も講じている。

以上のように，「海外旅行」の目的地となる 国・地域の増加や，中国政府による観光政策の 整備などによって, 中国人の「海外旅行」は拡大 している。また，旅行会社が実施している「海外 旅行」のツアーでは, 個人旅行志向の高まり, ツ アー内容の多様化などの特徴がみられることが明 らかになった。

\section{III. 中国人観光旅行に対する日本の注目}

中国人の海外への旅行が活発化する中で，日 本への団体観光客数も順調に増加している（図 3)。それでは，日本の受け入れ機関はどのよう な対応や誘致活動を行ってきたのだろうか。日本 の旅行会社のなかには，中国人の訪日観光旅行の 取扱認可を取得し，新たなマーケットを獲得しよ うとする動きがある。また，近年では，特に中国 人を中心として，外国人観光客を誘致しようとす る自治体も増加しつつある。以前から誘致活動が 行われている地域でも, 観光客の増加が鈍化しつ 
つあるところでは，新たな誘致対象として中国人 観光客の重要性が認識されつつある。本章では, 中国人の訪日旅行のなかでも，とくに団体観光旅 行に焦点を当て, 旅行業界や自治体がどのような 誘致を行ってきたのかについて検討する。
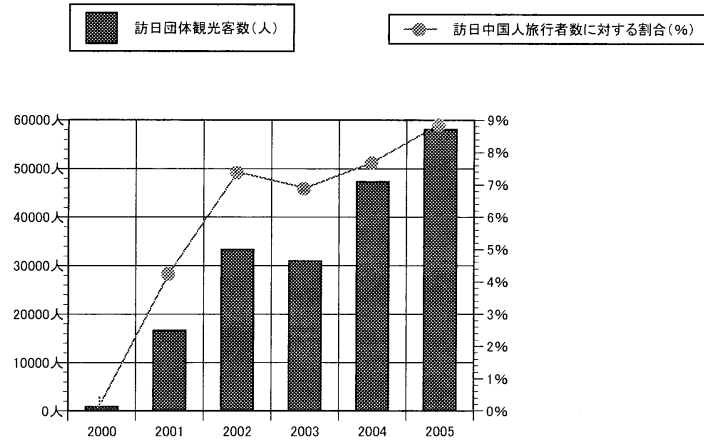

図 3 中国人訪日団体観光客数の推移 資料：国際観光振興機構編 (2006b) をもとに作成。

\section{1. 中国人の訪日観光旅行に関するシステム}

（1）中国人の訪日観光旅行者をめぐる制度

中国人が査証の相互免除が行われていない国・ 地域へ「出境旅行」を行う場合は，旅券に加え て, 旅行目的に応じた当該国政府の査証が必要と なる。就労や留学などの長期滞在を除く短期滞在 查証の種類は, 商用 (商談, 研修, 視察, 技術交 流など），親族訪問，団体観光等に区分されてい る。

訪日団体観光旅行のための査証を取得するに は, 旅券, 査証申請書, 居住証明, 所得証明, 在 職証明，滞在日程表の提出に加え，査証申請に関 する代行業務を行う旅行会社に対して，5万元か ら20万元（約75万円～300万円）の保証金を預け る必要がある。保証金の金額は, 代行業務を行う 旅行会社で決定され, 申請者の出身地が不法滞在 者を多く出している地域の場合には，保証金の金 額が高くなる場合もあるという。また，旅行者が 提出する書類の状況によっては, 面談が実施され ることもある。

現在では, 手続きの簡略化が図られつつあるも のの, この査証取得の煩雑さは, 依然として海外 旅行を行ううえでの障壁の一つとなっている
（2）査証発給対象地域の拡大

日本と中国は，実務者会議において中国人訪 日団体観光旅行について合意に達し，2000年 9 月 に, 北京市, 上海市, 広東省を訪日団体観光旅行 の試験地域として指定することを決定した ${ }^{9)}$ 。ま た，訪日団体観光旅行を取り扱う旅行会社とし て, 中国側では海外渡航業務の取り扱いを許可さ れている旅行会社 20 社が指定され, 日本側では国 土交通省の募集によって63社が指定された。査証 の取扱公館は，北京の日本大使館に加えて，2003 年に在上海総領事館と在広州総領事館でも発給が 開始された。

2004年 9 月には, 査証発給地域が拡大し, 天津 市, 遼寧省, 山東省, 江蘇省, 浙江省が追加され た。同時に，取扱旅行会社が新たに指定され，日 本側では78社, 中国側では192社となった。さら に, 2005年 7 月には, 査証発給対象地域が中国全 土に拡大され, 日本側の取扱旅行会社は2004年に 128 社に, 中国側の取扱旅行会社は2005年に672社 に増加した ${ }^{10\rangle}$ 。

2005年に解禁された地域では, 訪日観光のツ アーはまだ少なく，旅行者が集まらないためにツ アーが催行できないという状況も発生している。 これらの地域からの訪日ッアーの場合, 北京市の 旅行会社数社が査証の申請を代行するとされてい る。そのため, ッアーの参加者を集めた現地の旅 行会社は, 北京市の旅行会社を経由して在北京日 本大使館に査証を申請しなければならず，北京市 の旅行会社と現地の旅行会社の間では, 手数料な どの金銭的な取引も発生する。このため, 2005年 に解禁された地域の旅行会社は, 他の地域の旅行 会社と比較して, 訪日観光のッアーを催行しにく い。JNTO北京事務所は「2005年に解禁された地 域の旅行会社は, 訪日観光のツアーに対してまだ 様子をみている状況にある」と話している ${ }^{11)} 。$

\section{（3）日本側の旅行会社に対する規制}

日本側の旅行会社が訪日団体観光旅行を取り 扱うことに関する規則や制度は，国土交通省観 光部によって作成された『訪日団体観光旅行取扱 マニュアル』や『中華人民共和国国民訪日団体観 光旅行取扱契約における必要記載事項』などに記 載されている。中国の旅行会社が日本大使館・総 
領事館に査証の代理申請を行うためには，日本側 の旅行会社が作成した招聘保証書が必要となる。 また，形式は団体旅行のみに限られ，1回のツ アーの人数は 5 名以上 40 名以下とされている。査 証は，発給の日から 3 ケ月間有効であり，15日間 の滞在が認められる短期滞在査証に限定されてい る。

また，国土交通省は，中国人旅行者の逃亡・不 法滞在の防止を目的として, 日本側の指定旅行会

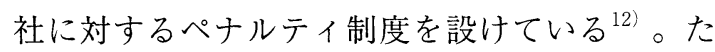
とえば，団体観光旅行中に中国人旅行者が逃亡し た場合，取り扱いを行った旅行会社の過失の度合 いに応じて減点ポイントが与えられる。そして, その減点数に応じて, 中国人観光旅行取り扱い停 止などの処分がなされる。このため，中国人の訪 日観光旅行を取り扱うことは，日本の旅行会社に とって,リスクを背負うことにもなる。

\section{2. 旅行会社による中国人観光旅行の取り扱い}

前節で確認したように，旅行会社が中国人の訪 日観光旅行を扱うには，さまざまな制約やリスク を伴う状況にある。しかし，一方では，そのよう な制約に対応しながら, 団体観光旅行の市場の潜 在性に着目して業務を行おうとする旅行会社も存 在する。以下では, 清水・祖田（2005）を参照し ながら，そのような旅行会社の取り組みの一例を 紹介しよう。

北海道に所在する旅行会社 $\mathrm{A}$ 社は，2000年に中 国人訪日観光旅行の解禁に伴って行われた取扱旅行 会社の第 1 次募集で, 取扱認可を取得している ${ }^{13)}$ 。

$\mathrm{A}$ 社は，2000年に設立され，道内に14の店舗を持 つ旅行会社で, 中心的な業務は, 日本人の中国旅 行取り扱いであるが，2004年の時点では，中国人 観光客の訪日旅行も重要な業務としていた。

$\mathrm{A}$ 社は, 中国人の訪日観光旅行に関して, 行程 に北海道が含まれる, 価格の高いッアーだけを扱 うという方針を採っていた。これは，旅行者が日 本での逃亡・不法滞在を目的としている場合, 価 格の安いツアーを選ぶ傾向があるからである。ま た，旅行代金の回収については，「中国側で認可 を受けている21社（当時）の旅行会社の中でも， 安心できる会社とだけ付き合う」としており, 慎 重な姿勢が感じられた。
一方で $\mathrm{A}$ 社は, 台湾・香港などからの旅行につ いてはリスクが少ないものの, 日本側の旅行会社 が利益をあげにくいという点があることも指摘し ている。台湾や香港などからの訪日旅行では，日 本の旅行会社を利用しない個人旅行が増加してい るため, 今後旅行会社が利益を上げることが難し くなる可能性がある。それに対して，中国からの 訪日観光旅行では, 日本側の旅行会社から招聘理 由書を発行する必要があり，また，旅行中は日本 人の添乗員の同行が義務付けられるなど，日本側 の旅行会社が必ず手配の過程に介在する必要があ る。さらに, 中国の旅行会社に訪日観光旅行のノ ウハウが蓄積されていない段階において，日本の 旅行会社が果たしうる役割も大きいという。A社 は，これらの点に注目して，中国からの観光旅行 の業務を開始したと考えられる。

同じようなことは，大手旅行会社のグループ企 業であるB社（在札幌市）も指摘している。中国 からのツアーは, 他社との競争が激しい台湾や韓 国などからのッアーと比較して利益が挙げやすい という。これらの旅行会社は, 中国の訪日観光旅 行市場が，発展・整備の段階にあることに注目し た動きであったといえる。

\section{3. 自治体の中国人観光旅行に対する取り組み}

前節で紹介したように，一部の旅行会社は，中 国人観光客の訪日旅行に注目して業務を行ってい た。一方, 日本の自治体のあいだでも，異なる視 点から中国人旅行者に注目する動きがみられる。 本節では, 中国人観光客に対する誘致活動と, そ の考え方について検討したい。

自治体の中国人観光客誘致活動に関しては, 2000年 9 月に訪日団体観光旅行が解禁されたこと などから，次第に関心が向けられつつある。ま た, ビジット・ジャパン・キャンペーンの関連事 業として，たとえば，「栃木県への中国人観光客 誘致推進プロジェクト事業」など, 国土交通省と の提携による誘致活動も多くの自治体で行われて いる。

中国と日本の自治体の友好都市提携も活発に 進められている（表 1）。自治体国際化協会北京 事務所次長のC氏によると，これまで自治体の友 好都市提携は, アメリカやヨーロッパを中心に 
行われていた。しかし，「自治体の財政的な状 況から,メリットを持たない部門の削減が求めら れ, 国際交流を中心としたそれらの都市との友好 都市提携は維持することが難しくなっている」と (j ${ }^{14\rangle}$ 。一方, 中国の自治体との友好都市提携 では, 地元産品の販売, 企業の進出, 旅行者の誘 致などを行うことができるため，自治体は友好都 市提携を結ぶ理由を見出しやすいという事情があ る。このように，日本の自治体は，中国人観光者 の誘致や企業の中国進出などで得られる経済的な メリットの大きさから，中国に注目しているとい える。

\begin{tabular}{cc} 
表 1 日本の自治体の友好都市提携数 \\
\hline アメリカ合衆国 & 435 \\
中国 & 310 \\
オーストラリア & 108 \\
韓国 & 104 \\
カナダ & 69 \\
ブラジル & 59
\end{tabular}

資料：自治体国際化協会 $(2005 \mathrm{~b})$ をもとに作成。

ここでは，自治体が中国人観光客の誘致活動 を行っている具体例として，札幌市を取り上げた い。2000年に中国からの訪日観光旅行が解禁され た後も, 台湾に対する誘致活動を中心に行ってき た北海道とは異なり，札幌市では，早期から中国 人旅行者の市場の潜在性に注目し, 活発な誘致活 動を行ってきた（清水・祖田, 2005）。

札幌市は, 日本の他地域の自治体が中国に注目 し誘致活動を積極的に展開しつつあることも念頭 に置き，他の自治体に先駆けて，札幌市の観光地 イメージを中国に浸透させることを強く意識して きた。たとえば，2004年 4 月からは，北京市の一 部の路線バスに, 札幌の雪祭りや時計台の絵柄を 塗装し, 観光地としての札幌市を宣伝する試みを 行った。2003年11月には, 札幌市初の海外駐在員 事務所（札幌経済交流室）を北京に設置し，中国 人観光客の誘致活動と, 札幌市内の企業に対する 中国進出への支援を行っている。

筆者は2005年12月に, 札幌経済交流室のD氏に 対する聞き取り調査を行った。交流室の活動とし ては, 札幌市の旅行展示会出展の支援や, 中国政
府・マスメディアに対する観光プロモーション の実施がある。しかし，このような観光プロモー ションに対して，D氏は，「日本の自治体のプロ モーションは, 毎回パワーポイントを利用して 同じような形式で行われているため，飽きられな いような方法を考えなければいけない」と指摘し ている。また，「中国人は，訪日旅行といえば東 京や大阪を訪れるものだいうイメージを持って いて，その他の多くの自治体は名前も認知されて いない。地方の自治体の中には, 名刺の裏に日本 地図を印刷し, 自治体の位置を説明している担当 者もいる」という。北海道や札幌市の行っている 観光プロモーションについても，「説明会の終了 後, 中国の旅行会社と商談会や食事会を行うとい う流れが固定化している」という状況がある。こ の打開策として, 札幌市では, 著名な中国人作家 を北海道に招いて旅行記の執筆を依頼するなど, 新しいプロモーションの方法も実践している。こ のほか, 新聞広告の掲載やパンフレットの配布, ポスターの作成など, 紙媒体によるプロモーショ ンも行われている。

しかしその一方で，D氏は，「日本と異なり， 中国では新聞を見る所得者層が限られている。 また, 街頭で印刷物を配布することも法律で禁じ られている。そのため, 限られた予算の中でどの ように効率的な宣伝を行うかに苦労している」と 述べ，中国で観光プロモーションを行うことの難 しさを強調する。つまり, 今後中国人観光客が増 加していくことは確実だが, 海外旅行を行うこと ができる中国人は一部に限られているため, 誘致 の対象を絞ることが重要になるという。D氏は,

「札幌市が遼寧省大連市で行った調査から判断す れば, 大連市の人口約550万人の中で実際に海外 旅行を行うことができる所得者層は，全体の $1 \%$ 程度ではないだろうか」と考えており，中国人の 訪日観光旅行の市場については，その潜在性に対 する一部自治体の期待と, 実際の状況とのあいだ に，大きな落差があることを指摘している。

\section{4. 観光客誘致からのシフト}

筆者が2004年に行った聞き取り調査では, 解禁 直後の中国人観光客の取り込みに重点を扔く旅 行会社や自治体が, 確かに存在した。旅行会社と 
しては, 逃亡・不法滞在防止などの目的からさま ざまな規制が設けられている一方で，そうした制 約があることで，逆に利益を上げることができた のも事実である。また，中国における旅行市場が 未成熟であったという点も, 日本の旅行会社には 有利に働いた。一方, 自治体の姿勢としては, 財 政状況の悪化などを背景に, 交流対象を経済的な メリットが得やすい中国へとシフトする傾向にあ り, 同時に中国人観光客の誘致を積極的に行う方 向にあった。

ところが，札幌経済交流室D氏の話にもあった ように, 日本の各自治体の行っているプロモー ションが必ずしも成果に結び付けられていない という現状があり，中国人のなかで実際に海外旅 行を行うことができるのはごく少数であるという ことを指摘する声も聞かれる。このような状況か ら，日本の各自治体では，「観光客以外」の中国 人旅行者に注目しょうとする動きもみられる。次 章では,この点について検討する。

\section{IV. 中国人訪日旅行の多様化}

\section{1. 中国人「観光」旅行の占める位置}

前章では，中国人の訪日観光旅行に焦点を当て て検討した。確かに, 訪日観光旅行の解禁以降, 中国人観光客の増加は著しい。ところが, 観光業 界や自治体のあいだでは, 単なる観光客の誘致で はなく, 別の形態での中国人旅行者の獲得を模索
し始めている。ここでは，まず，中国人の「観光 客」が実際にはどのような存在として捉えられる べきを，統計的資料を参考に考察しよう。

図 2 で見たように，2000年以降，私用旅券を 利用した中国人の「出境旅行」が急増してい る。そうしたなか, 訪日旅行も急激な増加を見 ている。2005年の中国人の訪日旅行者数は, 前 年比 $6.0 \%$ 増の 65 万 2,820 人を記録した（表 2$) 。$ 中国人の訪日旅行を目的別に見ると，観光客が 20 万 1,940 人 $(30.9 \%)$ ，商用客が 16 万 5,394 人 (25.3\%)，その他客が25万6.739人 (39.3\%) などとなっており, 観光客だけでなく, 商用・そ の他の旅行者の増加も著しい。現在のところ, 割 合として観光客が最も多いとはいえ，そのシェア は3割程度であり，それ以外が 7 割を占める現状 に扔いて，旅行会社や自治体が「観光客以外」に 注目することは，招そらく自然なことであろう。

ここでは，国際観光振興機構編 (2005a) か ら, 訪日目的別の旅行形態とその割合を少し詳 しく見てみよう（表 3 ）。この報告書で調査対 象となっている中国人旅行者数は884人で，その サンプル数から見て，必ずしも実態を表してい るとは限らないが, おおよその傾向は把握でき る。これら884人の旅行者のうちで, 最も高い割 合を示しているのは，「業務」による訪日旅行 で，サンプル全体の $43.5 \%$ 占める。その他の訪 日目的では, 割合の大きい順に, 親族・友人訪

表 2 目的別訪日中国人旅行者数

\begin{tabular}{|c|c|c|c|c|c|c|}
\hline & & 総 & 観 光 客 & 用 & その他客 & 一時上陸客 \\
\hline \multirow{3}{*}{ 2001年 } & 人 数 (人) & 391,384 & 72,118 & 74,309 & 194,174 & 50,783 \\
\hline & 構成比（\%) & 100 & 18.4 & 19 & 49.6 & 13 \\
\hline & 伸び率（\%) & 11.3 & 59.3 & -4 & 12 & -9 \\
\hline \multirow{3}{*}{ 2002年 } & 人 数 (人) & 452,420 & 101,299 & 91,189 & 220,573 & 39,359 \\
\hline & 構成比（\%） & 100 & 22.4 & 20.2 & 48.8 & 8.7 \\
\hline & 伸び率（\%） & 15.6 & 40.5 & 22.7 & 13.6 & -22.5 \\
\hline \multirow{3}{*}{ 2003年 } & 人 数（人） & 448,782 & 95,991 & 96,177 & 226,570 & 30,044 \\
\hline & 構成比（\%） & 100 & 21.4 & 21.4 & 50.5 & 6.7 \\
\hline & 伸び率（\%) & -0.8 & -5.2 & 5.5 & 2.7 & -23.7 \\
\hline \multirow{3}{*}{ 2004年 } & 人 数 (人) & 616,009 & 189,692 & 141,204 & 254,453 & 30,660 \\
\hline & 構成比（\%） & 100 & 30.8 & 22.9 & 41.3 & 5 \\
\hline & 伸び率（\%） & 37.3 & 97.6 & 46.8 & 12.3 & 2.1 \\
\hline \multirow{3}{*}{ 2005年 } & 人 数 (人) & 652,820 & 201,940 & 165,394 & 256,739 & 28,747 \\
\hline & 構成比（\%) & 100 & 30.9 & 25.3 & 39.3 & 4.4 \\
\hline & 伸び率（\%） & 37.3 & 6.5 & 17.1 & 0.9 & -6.2 \\
\hline
\end{tabular}

資料：国際観光振興機構編（2006b）をもとに作成。 
表 3 中国人の訪日目的別旅行形態

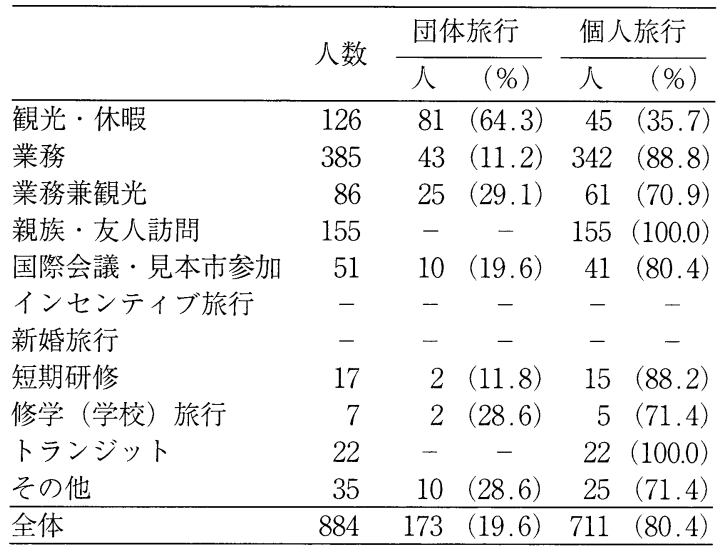

資料：国際観光振興機構編（2005）をもとに作成。

問（17.5\%），観光・休㗇（14.3\%），業務兼観 光 $(9.7 \%)$, 国際会議・見本市参加 $(5.8 \%)$ と なっている。また，旅行形態を見ると，団体旅行 $19.6 \%$ ，個人旅行 $80.4 \%$ となって抢り，「観光・ 休暇」以外の旅行では，その多くが個人旅行の形 式で行われている。

実は，中国からの「出境旅行」全体の中で見た 場合，いわゆる「観光」を目的とするような，旅 行会社の提供するツアーはそれほど重要な位置づ けにあるわけではない。図 4 は, 中国国家旅游局 の資料をもとに作成したものであるが，そこに占 める旅行会社のツアーによる旅行者数は伸び悩ん でおり，年々その相対的地位を低下させているこ とが分かる。

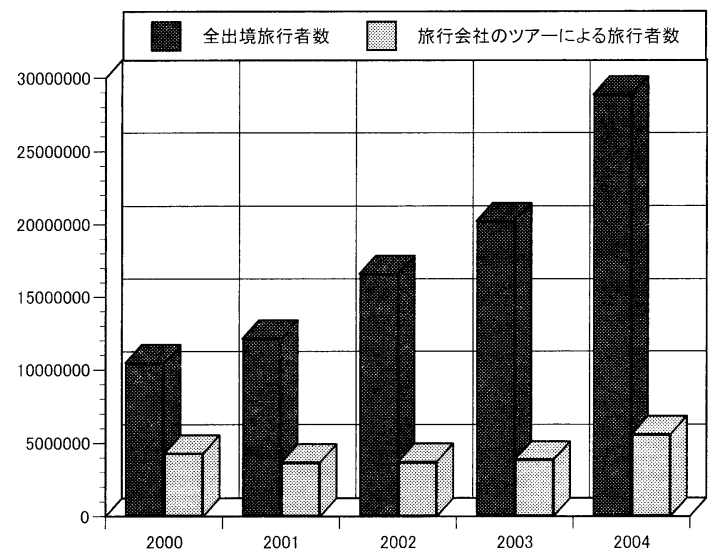

図 4 旅行会社のッアーによる旅行者数の全出境旅 行者数に対する割合

資料：中国国家旅游局 (2001 2005)をもとに作成。
このように, 中国からの「出境旅行」者全体 から見ても，そのうちの訪日旅行者全体から見て も, 観光客の占める位置というのは, 実はそれほ ど高くないということが分かる。もちろん，2000 年の訪日観光旅行の解禁以来, 多くの旅行会社や 自治体が，中国人観光客の獲得に積極的であった ことは，前章で確認したとおりである。しかし， そうした状況も，急速に変化しつつある。その変 化として，たとえば，中国からの観光旅行の取り 扱いを停止する旅行会社や, 取扱認可を取得して も観光旅行を扱わないという旅行会社が増加して いることが挙げられる。前章で紹介した $\mathrm{A}$ 社も, 中国人観光客の扱いに積極的であった旅行会社 だが，現在では，中国からの観光旅行に関する業 務を行わず，日本人の訪中旅行のみを扱うように なったという。また，自治体の中にも，観光客の 誘致に取り組むだけではなく，「観光客以外」の 中国人旅行者を誘致しようとする取り組みも始め られている。次節以降では, こうしたターゲット のシフトが起こっている要因と,「観光客以外」 の旅行者獲得の具体的な事例について見ていくこ とにしよう。

\section{2. 訪日観光ツアーの競争激化と劣悪化}

日本の旅行会社が中国からの観光旅行を敬遠 するようになった要因として, 中国の旅行会社に よって販売される, 訪日観光ツアーの価格の急激 な低下という事態がある。本節では, 次節以降の 議論の前提として, 訪日観光ツアーの内容の変化 について，価格の面を中心に検討する。

中国人訪日観光ツアーは, 主に中国の旅行会 社によって企画される。訪日旅行市場では出国 管理や查証の取得などに関して制約が大きいこと から，特徵を持ったツアーを企画することは難し く, 各旅行会社のッアーは, 内容が似通ったもの となる傾向にある。また, 国際観光振興機構北京 事務所によれば, 中国の旅行会社では訪日旅行に ついて知識を持つ人材が不足していることから， ッアーの企画は，他社の人気ツアーを模倣し， かつ価格を下げるという方式で行われているとい う。このような状況から, 訪日団体ツアーの価格 も大幅に低下しつつある ${ }^{15)}$ 。

まず，中国からの訪日観光旅行のッアー価格 
の変遷を見てみよう。何・陳（1997）に記載され た情報は，訪日観光旅行解禁前に発表されたモデ ルコースであるが，この当時の価格設定（当時予 定）を見ると, 東京, 横浜, 名古屋, 京都, 大 阪をまわる 5 泊 6 日のツアーで 1 万 7,500 元（約 26万5,000円）となっている。掲載されているモ デルコースは，いずれも東京から入国し，大阪か ら出国する旅程で, 東京の観光地を見学した後, 箱根, 名古屋, 京都などを訪れる内容となってい る $^{16)}$ 。

一方，2002年に実際に行われた訪日観光ツアー の事例をみると, 東京, 横浜, 京都, 大阪をま わる 5 泊 6 日のツアーの価格は，上述したモデル コースとほぼ同じ内容であるにもかかわらず， 価格は9,800元（約14万8,000円）まで低下してい る。そして，2005年 2 月には，5泊 6 日の行程 で, 6,380 元（約 9 万7,000円）の訪日観光ツアー も現われている。

このように急速に価格の低下が進んでいる背景 として，ヨーロッパやオセアニアなど, 観光地と して人気の高い地域が相次いで海外旅行の目的地 に加わったことや，東南アジアなどへのッアーの 価格低下の影響を受けたことなどが挙げられる。

このような低価格の訪日観光ツアーには, 消費 者の苦情を招くような品質の低いッアーも多く, 観光地としての日本イメージの低下も懸念されて いる。このため, JNTOや地方自治体などでは, 中国の旅行会社を支援し，品質の高い訪日観光ツ アーの造成に努めてきた努)。その一方で，日本 側・中国側の双方で訪日観光旅行の取扱認可を受 ける会社が増加し, 価格競争の激化と, ッアー内 容の劣悪化という事態は, いっそう進行しつつあ る。こうしたことから，日本の旅行会社は，中国 人の団体観光旅行から撤退する動きも顕著になり つつある。それでは，日本の旅行会社は，中国人 の訪日旅行に対してどのような対応をとっている のだろうか。この点について, 次節で具体的事例 を見てみよう。

\section{3. 日本の旅行会社による中国人商用旅行の取り 扱い}

（1）E社による商用旅行の取り扱い

E社は, 東京都に所在する大手旅行社の 1 つで
ある。E社は 2000 年に中国人訪日団体観光旅行の 取扱認可を受けている。また，2006年 2 月には， 同様の取扱認可を受けた中国専門の旅行会社の全 営業権を獲得した。こうしたことから，E社は中 国旅行に関する業務に注目していることがうかが える。

ところが，E社はこれまでのところ，中国人の 訪日観光旅行に関する業務は行っていない。現 在E社が扱っているのは, すべて商用旅行で, 過 去 3 年間では毎年 2,000 人程度の旅行者を受け入 れている。これには, 収益性の問題が大きく関連 している。E社の担当者は, 日本人旅行者や他の 地域からの外国人旅行者に関する業務と比較した 場合，「特に中国人の訪日観光旅行の収益性は悪 い」と述べている ${ }^{18)}$ 。その背景には，前節で述 ベたような，訪日観光ツアーの急激な価格低下が ある。E社の担当者は, 「最近では, 訪日観光ツ アーでは，全体の95\%以上が華僑などアジア系の

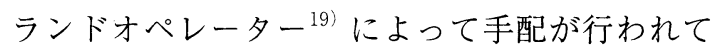
いるという事情がある」と述べ，それらの会社 は，ツアーのコストを抑えるために，移動中の バスで車内販売を行ったり, 留学生を添乗員とし て雇ったりして利益を上げている20) という。E社 では, こうした観光旅行の取り扱いは避けて，中 国人訪日旅行の取り扱いを商用旅行に限定してい るため, 収益性は中国人訪日旅行全般を扱ってい る他社と比較して僅かに高いという。また，中国 人訪日旅行を扱っている他の東京都の大手旅行社 も，E社と同様に，商用旅行を中心に扱う傾向が あるとしている。

E社の担当者によると, 観光目的の查証を取得 することが難しいことから，中国人旅行者の中に は，短期商用の查証で訪日しながらも，実際には 観光だけを行うという事例が少なくないという。 団体形式に限られている観光旅行では, 自由行動 が認められず，訪問したい観光地に行くことがで きないため，「不満を持った旅行者の中には，商 用の査証を使うなど, 他の手段で再度, 訪日旅行 をすることもある」という。

確かに，商用の查証を申請する場合でも，日本 側の企業の招聘理由書などが必要とされる ${ }^{21)} 。$ しかし，一定の地位と手段を持っている人にとっ ては，観光用査証を取得するよりも商用の查証を 
取得する方が，はるかに障壁が少ない。E社の担 当者は，「商用の査証が取得できるかどうかは, 旅行者によって異なる」としながらも，「商用の 查証を使用して，週末ごとに買い物の目的で訪日 し2 泊 3 日で帰国する例や，観光旅行で訪問でき なかった観光地を, 商用旅行で訪日して訪れる例 がある」という。

こうした商用査証による訪日旅行は, 査証申請 の際に外務省の審査があることから，すべての中 国人旅行者が行えるものではない。しかし，E社 の担当者は，「費用があれば，どこかの企業を経 由して商用の査証を取得することもできる」と話 しており，こうした商用査証による「観光旅行」 は数多く行われていると考えられる。E社は，こ うした中国人旅行者を中心に取り扱うことで，リ スク回避と利益の獲得を狙っているといえる。

（2）F社による商用旅行の取り扱い

F社は，1997年に設立された中国人の商用旅行 を中心に扱う旅行会社である。所在地は北海道札 幌市で，旅行業のほかに，中国語の翻訳業や輸入 業務，広告物の制作など，中国に関連する業務を 広範に行っている ${ }^{22)}$ 。

$\mathrm{F}$ 社は, 1 ケ月に 20 件程度の商用旅行を取り 扱っている。20件中の多くは 5 名から10名の商用 旅行で, その内 $3 \sim 5$ 件程度は中国の日系企業の 社員旅行を扱っている。F社は, 現在のところ, 中国からの観光旅行を取り扱う方針を持っておら ず，訪日観光旅行の取扱認可も取得していない。 ここでは，F社が，観光旅行を扱わず商用旅行を 扱っている理由を，3点に分けて検討する。

まずF社は，観光旅行を取り扱わない最大の理 由として，「観光旅行の価格競争に参入したくな い」という点を挙げている。F社によれば, 観光 旅行の収益性は悪く，30４0名で訪日する観光旅 行よりも，5名前後で訪日寸る商用旅行のほうが 高い利益を上げられる場合もあるという。

第 2 に，F社は，商用旅行の手配における，融 通性の高さを指摘している。観光旅行の場合は, 日本滞在中の旅程が事前に固定され, 自由行動も 原則として認められていない。これに対して, 商 用旅行では, 事前に滞在日程表の提出が求められ るものの, 日程表による拘束はなく, 変更も自由
に行われている。このため, 少人数の商用旅行の 場合, 食事の手配等も, 必ずしも事前に行う必要 はない。また，観光旅行では，規則によって日中 双方から添乗員をつけることが決められているの に対して, 商用旅行では, 添乗員の手配を必要と しないという利点がある。

観光旅行を扱わない 3 点目の理由として，代金 回収の問題も挙げている。中国側の旅行会社から 日本側の旅行会社への代金の支払いは，中国企業 の商取引の慣習から，一般的に後払いであること が多い。しかも，その代金の支払いが長期間滞る こともある。F社によれば，観光旅行を取り扱っ ている一部の旅行会社では, 日本人の訪中旅行で 発生する代金と相殺する「バーター取引」によっ て，代金回収の問題に対応しているという。商用 旅行の場合では，中国の旅行会社を経由せず，信 頼関係を築いている企業との個別の取引が主であ るため, 代金回収の問題は観光旅行と比較して小 さいものとなる。

また, F社は, 代金回収の問題と関連して, 「中国の企業と取引を行ううえでは, 個人と個人 の関係が非常に重要である」ということを強調し ている。したがって, 中国の企業が商用旅行の手 配を依頼する際には，担当者が頻繁に入れ替えら れる大規模な旅行会社ではなく, 個人的な関係を 継続・維持できる旅行会社を使う傾向にある。

F社は，今後の方針についても，「近いうち に, 観光旅行を取り扱う可能性はある」としてい るものの, 観光旅行を業務の中心とする計画はな く, 商用旅行を主体として業務を継続するとして いる。

\section{4. 自治体の中国人修学旅行に対する取り組み}

前節では，旅行会社のあいだでは，観光旅行で はなく商用旅行に特化して中国からの訪日旅行を 行う会社が増加しつつあるという点を指摘した。 一方, 受け入れの別の主体である自治体におい ても，中国から観光客ばかりを誘致するのではな く, 観光以外の訪日旅行者に注目して誘致活動に 取り組もうとする動きがみられる。

筆者が2006年4月におこなった，自治体国際化 協会の北京事務所次長C氏に対する聞き取り調査 によれば, 現在, 多くの自治体が誘致活動の対象 
として注目しているのが, 中国から日本への修学 旅行だという。「訪日修学旅行では, 日本側で教 育プログラムなどを考え, 中国側の要求に沿った ものを提供できることが強みだ」とC氏は話して いる。修学旅行では査証が免除されている点が送 り出し・受け入れ双方にとって大きな利点となっ ており，また，1回の旅行あたりに訪日する人数 が多い点も, 受け入れ側にとっては重要な意味を 持つ。

ここでは, 修学旅行の誘致など, 中国からの誘 致活動に新しい取り組みをみせる自治体の具体例 として, 長崎県を取り上げたい。長崎県は, 外国 人旅行者の誘致活動に早期から取り組んでいる自 治体のひとつで, 韓国や香港, 中国など, 東アジ ア各地からの旅行者の誘致に積極的に取り組んで いる。以下では，『トラベルジャーナル』（2003 年 6 月 9 日号）の記事を参照しながら, 長崎県の 中国人旅行者誘致活動と, 修学旅行への取り組み について紹介しよう。

長崎県は, 上海市と友好交流都市提携を結ん でおり, 上海市からの観光視察団の招聘, 上海 一長崎間の定期航空路線利用促進のためのプロ モーションなど, 上海市を主な対象として活動が 行われている。このほか, 長崎県観光連盟では, 国際旅行展への出展や新聞などへの広告掲載のみ ではなく，「長崎方式」と呼ばれる誘致活動を展 開している。従来, 日本の自治体が中国に対して 行う観光プロモーションでは，旅行関連企業の担 当者やマスメディアなどが集められ，大人数で中 国を訪れる方式が中心であった。しかし，長崎県 では，担当者を固定し，少人数で何度も中国を訪 れるという方式で活動を行っている。また，長崎 県の観光情報を中国に対して提供するだけではな く, 直接旅行会社を訪問し, 観光ツアーのコース を提案するなど, 積極的な取り組みもみられる。

一方, 修学旅行に対する取り組みとしては, 観 光連盟による単独のプロモーションのほか, 国土 交通省や他の自治体と合同で行われる「地方提携 事業」などを実践している。ながさき地域政策研 究所が発行している「平成16年度VJC事業の実施 報告」 ${ }^{23)}$ によれば，2004年12月に，中国人修学 旅行誘致のための事業として, 北京市の教職員, 生徒, 旅行会社, テレビ局を招聘し, 長崎県と大
阪市への視察旅行を行った。このほか, 中国全土 で訪日修学旅行に関するテレビ番組の放映も実施 し，また，中国の教育関係者に配布するDVDも 作成している。

こうした修学旅行に対する取り組みは, 継続的 に観光客を誘致することを狙いとして行われてい る。前述の『事業報告』では, 「多くの国々が中 国人観光客誘致合戦を展開している中で，一度訪 日を経験した旅行者が, 果たしてリピーターとし て日本を訪問してくれるのかは未だ不透明な部分 が多い」と指摘されている。こうしたなか, 学校 行事の一環としての訪日修学旅行を受け入れるこ とによって, 継続的な旅行者の獲得につながる。 また, とくに若い世代の訪日旅行は, リピーター の獲得にもつながる可能性がある。つまり, 継続 的な中国人旅行者の獲得を目的として, 修学旅行 が重要な誘致対象として位置づけられているので ある。

\section{V. 考察と結論}

本稿では, 中国から日本への訪日旅行につい て，2004〜2006年にかけて行った，旅行会社と自 治体に対する聞き取り調査などから，中国人の 訪日旅行に関する考察を行った。そのなかで明ら かになったことは、これまで観光旅行に注目して 誘致を行っていた日本の旅行会社や自治体が, そ の誘致対象を,「観光客以外」の旅行客へと転換 させつつあるということであった。特に，旅行会 社の中国人訪日旅行に対する姿勢では，2004年 4 〜 7 月に行った聞き取り調查と2006年11〜12月に 行った調査の間に, 明確な差異が認められた。

まず，旅行会社に関しては，観光旅行の取扱認 可を取得しながらも, 観光旅行の取り扱いを中止 した旅行会社や, 観光旅行よりも商用旅行を重視 する旅行会社があることなどが分かった。この理 由としては，訪日観光ツアーの急激な価格低下な どを背景に, 観光旅行の収益性が悪化しているこ とや，代金回収のリスクを回避できないことなど が挙げられる。

観光旅行の取扱認可を取得する旅行会社が, 国土交通省による追加募集などで増加している一 方で，実際には認可のみを取得し観光旅行を扱わ ない旅行会社が増えているということは, 注目し 
てよい現象である。しかし，必ずしも，観光旅行 の取り扱いが難しいという理由から, 商用旅行が 消極的に選択されているというわけではない。た とえば, 中国で発行されている旅行雑誌『时尚 旅游（TRAVELLER）』には，日本の観光地を 宣伝したモデルコースが掲載されているが，それ らは, 自由行動が認められない観光旅行では訪れ ることができない内容となっている。また，旅行 費用の節約方法なども書かれているほか，日本の 旅行在社の連絡先や, 各地方自治体の紹介文など も掲載されている。つまり, これらの記事は, 日 本の観光関連機関が, 中国の出版社に依頼して書 かれたものであることが容易に推察され，また， 対象としては, 商用査証を利用した訪日旅行者を 想定していることは明らかである。こうしたこと は，日本の観光関連機関が，積極的に商用査証を 利用した個人旅行者の誘致を行っていることの傍 証となるであろう。

一方, 自治体の中国人訪日旅行に対する取り組 みにおいても，観光旅行だけにとどまらず，修学 旅行の誘致など多様な方法が模索されていること が明らかになった。この背景には, 自治体が中国 で行っている観光プロモーションからは, 直接的 な成果を得ることが難しいという事情も存在して いる。このため, 修学旅行の誘致によって, 中国 側と人的な関係を構築し, 継続的に旅行者を迎え 入れようとする試みが行われているのである。

ところで，中国からの訪日旅行に対する取り 組みに関して, 観光旅行だけではなく商用旅行や 修学旅行などに対しても注目が集められていると いう現在の状況は，日本におけるッーリズムのあ り方について何を示しているのだろうか。本稿の 第正章で紹介した，日本の自治体が行っている中 国人旅行者誘致の取り組みでは，その事業名など に「観光客」という用語が多く用いられていた。 また，旅行会社の取り組みに関しても，中国から の観光旅行では旅行会社が必ず手配の過程に介在 することができるという理由から，中国の訪日旅 行市場に注目しているという会社がみられた。こ れらのことから, 日本のインバウンド・ッーリズ ムに挄いて注目を集めていたのは，日本を訪れる 旅行者のすべてではなく, 観光を直接の目的とし て訪日する旅行者であったという傾向がうかがえ
る。

しかし，第 $I V$ 章の内容からは，旅行会社や自 治体に打いて, 商用旅行や修学旅行など, 観光旅 行以外の旅行形式にも急速に取り組みの対象が広 がっていることが明らかになった。これは，観光 の定義に即して言えば, これまで日本において狭 義的に捉えられることの多かった「観光」が，商 用旅行などを含めた広義の「観光」へと変化して いるということである。中国人訪日旅行では，商 用の查証で訪日し実際には観光を行うという事例 も多数みられ, 日本における観光の定義には合致 しない特徵も有している。本稿で取り上げた中国 人訪日旅行は, 現在, ツーリズム研究にみられる 「観光」の広義の解釈に論拠を与えているという 点に扔いて, 注目されるべき事象である。

日本における観光の定義は，1995年の観光政策 審議会の答申によれば，「余暇時間の中で，日 常生活圈を離れて行う, 様々な活動であって, 触れ合い，学び，遊ぶということを目的とする」 となっている。つまり, 日本においては, 観光 は「余暇活動の一つ」と認識されており（高寺, 2006），「兼観光 ${ }^{24)} 」$ と呼ばれるような, 観光 を主目的としない旅行は, これまで顧慮されるこ とが少なかったといえる。須田（2003）が，「世 に『観光』という言葉には, 多くの誤解や狭い 解釈が行われている。… (中略) …観光の内容 についても，いわゆる『物見遊山』的なもののみ と狭く考える風潮さえある」と指摘しているよう に，日本に打いては，「観光」という言葉は，観 光地をまわる周遊型のツアーのようなイメージと して認識されていたのである。

しかし, 現在の「ッーリズム」の定義では, 広 義に捉える解釈が主流となっている。WTO（世 界観光機関）の国際観光到着者数の定義では,

「訪問の主要な目的が, 訪問国内で報酬を得るた めの活動を行うこと以外の者で, 1 泊以上 12 か を超えない期間, 居住国以外の国で通常の生活環 境を離れて旅行する人」とされている。また，欧 米におけるッーリズム研究も, ツーリズムを余暇 活動の 1 つとして捉える考え方は支配的ではない

（高寺，2006）。たとえばドイッ観光学の代表的 な定義では，「ツーリストとは, 二つの条件を充 たす者である。一つは自分の居住地から離れてい 
る者で, その離れている時間が一年以内であるこ と。二つ目の条件は，その間，訪問先でお金を支 出するが，その技金は訪問地で稼いだものであっ てはならないということである」（Ogilvie, 1933）とされている。これらの定義では, 商用旅 行などを含めて「ツーリズム」として解釈するこ とが, 共通認識として成立しているといえる。

日本では，「観光」という言葉が，英語の 「ツーリズム」の訳語として長期にわたって使用 されてきた（小西・貴多野編，2002）。しかし, 小西・貴多野編も指摘するように，「観光」とい う用語では「ツーリズム」の意味が充分に表せな いということは明らかである。また，日本のッー リズム研究においても，「観光には，さらにビ ジネスや私用の旅行が含まれることもある」（安 村，1996）と指摘されているように，「観光」の 概念が拡大傾向にあることについて議論がなされ ている。

本稿で取り上げた中国人訪日旅行の実態は，こ れまで日本において用いられていた「観光」から 「ツーリズム」へと視野を広げようとする具体的 な事例として示唆的である。つまり，日本では， これまで「ッーリズム」の訳語として「観光」を 用いていたがゆえに，「ツーリズム」に関する諸 事象を正確に捉えきれていない側面があった。本 稿の事例は, 日本の政府や自治体, 旅行会社など にとっても，「観光」をより多様で幅広いものと

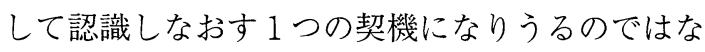
いだうか。

\section{注}

1) 本稿では, 「海外旅行」と表記した場合は, 中国国家 旅游局の定義するものを指し，括弧をつけずに，単に 海外旅行と記した場合は，一般的な意味での使用とす る。

2) 親族訪問旅行は、婚姻を含む 3 親等以内の血縁者が対 象となる。

3 ）国境旅行に関する制度は、国境地帯に居住する中国人 のために設けられているという面が大きいものの、隣 接する国から中国へ国境旅行を行うことも認められて いる。

4) ロシアは2004年 8 月まで海外旅行目的地として認可を 受けていなかったため、旅行会社によるッアーは行わ れず，国境旅行に限定されていた。2004年 8 月に正式
に海外旅行目的地として認可され、それと同時に、両 国間で旅行会社によるッアーの查証免除を決定した。

5 ）中国人の「海外旅行」の目的地となる国・地域は、中 国政府と当該国の交渉や中国政府の審査などを経て 決定される。一般的には、中国人旅行者の受け入れを 希望する当該国が中国政府に認可を要請し、中国政府 は、それまでの旅行者受け入れの実績や両国の交流状 況などを考慮して審査を行う。しかし、日本の例のよ うに、当該国の法務省や警察機関によって、治安管理 などの観点から、段階的な查証発給対象地域の拡大が 行われる場合もある。

6) この条例を機に、中国人の「出境旅行」は、「香港・ マカオ旅行」、「国境旅行」、「海外旅行」の $3 \supset$ つ カテゴリーに分けられることとなった。

7 ）本文中に打ける人民元から円への換算では、すべて 1 人民元 $=15$ 円として計算している。

8）中国・江蘇省で発刊されている揚子晚報（2005年 7 月 11日号) は、「江蘇省からの訪日団体観光旅行は2004 年 9 月に解禁されたものの、旅行の件数はこれまであ まり増えていない」と指摘し、その原因として、日本 の物価が高いこと、旅行の行程に時間の余裕がないこ と以外に、査証の取得が難しいことを挙げている。ま た、ヨーロッパへの観光旅行に扔いても、不法滞在者 の増加を背景に查証の審査が強化されているという状 況があり、江蘇省南京市の一部の旅行会社では、出境 旅行の重点地域を、日本やヨーロッパから、比較的查 証の取得が容易なオーストラリアに転換するという状 況もあると報じている。

9 ) 查証発給の対象は当該地域の戸籍所有者のみとされ、 戸籍のない居住者などの查証申請は認められていな い。

10）現在では、日本側の取扱旅行会社の募集形式は随時募 集に切り替えられている。2006年12月現在で取扱認可 を受けている日本側の旅行会社は、152社となってい る。

11） 2005 年12月15日の聞き取り調查より。

12）2005年に訪日団体観光旅行の査証発給対象地域が中国 全土に拡大されたことに伴い、『訪日団体観光旅行取 扱マニュアル』も一部見直しが行われた。日本旅行業 協会のホームページに揭載されている国土交通省の文 書によれば、短期間に多数の失踪者を出している旅行 会社については、取扱停止の期間を従来の期間より長 くすることや、取扱旅行会社としての選定基準に対す る適合状況の再確認が行われるなどの措置が採られる という。

13） $\mathrm{A}$ 社への聞き取り調查は、2004年 4 月と 7 月に行っ た。この時点では、北京市・上海市・広東省からの訪 
日観光旅行のみが認められている状況にあった。

14）2006年 4 月 12 日の聞き取り調査より。

15）中国では、春節（旧正月）や 5 月と 10 月の長期休㗇の 期間には、旅行者の急増に伴いツアーの価格が大きく 上昇し、それ以外の時期には、ツアーの価格が低下す る傾向にある。このため、繁忙期を避け、ツアーの 価格が低下する時期を待つ旅行者も多い。旅行会社で は、このような旅行者を取り込むために、閑散期のツ アーの価格をさらに下げる場合もある。

16）訪日観光ツアーのコースは、日中間の定期航空路線の 運航状況に大きく左右される。東京 · 大阪と北京 -上 海を結ぶ路線では定期便数が多く、航空会社間で価格 競争も行われることから、訪日観光ツアーの価格も安 くなる傾向がある。これに対して、中国への航空路線 が設けられていない日本の地方都市などでは、ツアー を造成することが難しく、誘致活動の範囲も限定され る。

17）たとえば、地方都市に滞在し、その都市の歴史や伝統 文化を体験するツアーや、映画や小説に縁のある観光 地を訪れるッアーなどが行われている。

18）2006年11月 7 日の聞き取り調査より。

19）ランドオペレーター（ツアーオペレーター）とは、ツ アーの参加者を募集する現地の旅行会社の依頼を受け て、海外旅行の食事、交通、宿泊などの手配を行う会 社を指す。中国人訪日団体観光旅行の場合では、中国 の旅行会社が、日本、または日本以外に所在するラン ドオペレーターに手配を依頼する。日本側の旅行会社 の業務は、団体観光旅行に参加する中国人旅行者の身 元保証や、添乗員の確保、査証申請のための招聘保証 書の発行などが主である。日本側の旅行会社が、中国 人訪日団体観光旅行のランドオペレーターの役割を兼 ねる場合もある。

20）中国人の訪日団体観光旅行には、日中双方から添乗員 を派遣することが義務付けられているが、このように 留学生を添乗員として派遣することは通訳案内業法や 旅行業法の法令に違反している。この状況は日本でも 問題視されており、2005年 4 月には、国土交通省総合 政策局から「無資格通訳ガイドの使用禁止の徹底につ いて」という警告の文書が出されている。

21）短期商用の査証を取得するには、申請者が査証申請 書、旅券、居住証明、在職証明、勤務先の営業許可証 の複写、戸籍謄本の複写を提出し、さらに旅行者を招 請する日本の団体から、招聘理由書、滞在日程表、身 元保証書、会社・団体概要説明書を提出することが求 められる。

22） F社に対する聞き取り調査は，2006年12月 8 日に行っ た。
23）この報告は，財団法人ながさき地域政策研究所の ホームページに揭載されているものを参照した。 http://www.think-nagasaki.or.jp/semina/17vjcjigyou/ $17 . h t m l （ 2007$ 年 4 月現在）。

24）『観光学辞典』（長谷編，1997）によれば、「兼観 光」は，「旅行をさらに細分化する際の用語で、出 張、業務、帰省、訪問、家事など観光を目的としない 旅行において、観光を行う旅行をいう。欧米ではこれ らを観光に含めるのが普通であるが、さらに細分化す るならばビジネス (商用)、VFR (visits to friends and relatives：友人・親戚への訪問）、その他とする 場合が多い」と説明されている。

\section{参考文献}

王興斌編 (2004)：『21世纪旅游业发展战略与经宫理全书』人 民日報出版社.

岡本伸之編 (2001)：『観光学入門 ポスト・マスッーリズ ムの観光学』有斐閣アルマ.

何礼䔉・陳喜増 (1997)：『中国国内旅游出境旅游实用手 册』旅游教育出版社.

国松博・鈴木勝 (2006)：『钼光大国 中国の未来』同友 館.

小池洋一・足羽洋保編 (1988)：『観光学概論』ミネルヴァ 書房.

国際観光振興機構編 (2003) : 『マーケティングマニュアル 2003』国際観光サービスセンター.

国際観光振興機構編 (2004)：『訪日外国人旅行者調査』国 際観光サービスセンター.

国際観光振興機構編 (2005a)：『JNTO訪日外客訪問地調 查2004-2005』国際観光サービスセンター.

国際観光振興機構編 (2005b)：『日本の国際観光統計』国 際観光サービスセンター。

国際観光振興機構編 (2006a)：『JNTO訪日旅行誘致ハン ドブック2005/2006』.

国際観光振興機構編 (2006b) : 『国際観光白書 世界と日本 の国際観光交流の動向 2006』

国土交通省編 (2006)：『観光白書 平成18年度版』国立印 刷局.

国家情報センター（2003）：『中国業種別発展レポート』中 国経済出版社.

国家旅游局 (2001)：『2001中国旅游统计便览』中華人民共 和国国家旅游局政策法規司。

国家旅游局 (2002)：『2002中国旅游统计便览』中華人民共 和国国家旅游局政策法規司.

国家旅游局 (2003)：『2003中国旅游统计便览』中華人民共 和国国家旅游局政策法規司。

国家旅游局（2004）: 『2004中国旅游统计便览』中華人民 
共和国国家旅游局政策法規司.

国家旅游局 (2005)：『2005中国旅游统计便览』中華人民共 和国国家旅游局政策法規司.

小西康生・貴多野乃武次編 (2002)：『現代ツーリズム研究 の諸相』神戸大学経済経営研究所.

顧林生・郭頌宏 (2000)：中国における観光政策の動向. 開 発こうほう，446，13-17.

塩澤潔(2001)：中国返還後の香港の旅行市場分析と訪日旅

行に関する考察．大阪明浄大学紀要， 1，39-50.

自治体国際化協会 $(2005 \mathrm{a})$ ：地方都市への中国人観光客の

誘致可能性について. CLAIR REPORT, 270.

自治体国際化協会 (2005b)：『北京事務所業務概要2005』

自治体国際化協会

清水伊織・祖田亮次 (2005)：北海道におけるアジアからの インバウンド・ッーリズム。北海道地理， 80，25-39.

鐘海生・郭英之 (2001)：『中国旅游市场需求与开发』広東 旅游出版社.

須田寛 (2003)：『新・観光資源論』交通新聞社.

須藤廣・遠藤英樹 (2005)：『観光社会学 ツーリズム研究 の冒険的試み』明石書店.

高寺奎一郎(2006)：『国際観光論』古今書院.

張広瑞 (2002)：『2000 2002年 中国旅游业发展的分析与

预测』社会科学文献出版社.

張広瑞 (2003)：『2001 2003年 中国旅游业发展的分析与 预测』社会科学文献出版社.

張広瑞 (2004)：『2002 2004年 中国旅游业发展的分析与 预测』社会科学文献出版社.

張広瑞 (2005)：『2003 2005年 中国旅游业发展的分析与 预测』社会科学文献出版社.

張広瑞 (2006)：『2004 2006年 中国旅游业发展的分析与

预测』社会科学文献出版社.

長谷政弘編 (1997)：『観光学辞典』同文舘出版.

平田真幸 (1999)：台湾からの「北海道旅行ブーム」はどの

ように生まれたか?ーデスティネーション・マーケティ

ングの視点からの考察—（アジア太平洋観光交流セン

夕ー「観光に関する学術研究論文」入選論文)

北海道 (2004a)：『北海道観光の概況』北海道経済部観光 振興課.

北海道 $(2004 \mathrm{~b})$ ：『平成 15 年度北海道観光客入込客数調査 報告書』北海道経済部観光振興課.

安村克己(1996)：観光社会学の現状と課題. 社会学評論,

47, 48-59.

山村順次 (1995)：『新観光地理学』大明堂.

吉田春生 (2003)：『エコツーリズムとマス・ツーリズム

現代観光の実像と課題』大明堂.

梁春香 (1998)：中国人の海外観光旅行と訪日観光市場. 月

刊観光, 385, 57-63.
Ogilvie, F. W.(1933) : The Tourist Movement: an Economic Study. London: P. S. King.

TRAVELJOURNAL (2003.6.9)：『新市場「中国」に広 域の連携で切り込む 全国縦断地方マーケット取材九 州(長崎＆福岡)編』株式会社トラベルジャーナル.

北京娛楽信報(2006.11. 27)：『欧洲自由行报价低于五千 岁末出境游开打价格战』北京日报报业集团.

国家旅游局 (2006)：中国旅游网〔http://www.cnta.gov.cn/〕

中国旅行社総社 (2006)：出境游报名手续〔http://www. ctsho.com/china/bm_c3.asp]

長崎県 (2006)：長崎県の統計〔http://www.pref.nagasaki. $\mathrm{jp} /$ toukei/]

日本旅行業協会 (2006)：訪日旅行〔http://www.jatanet.or.jp/honichi/]

楽途旅行 (2006)：出境游乐途旅游网〔http://www.lotour. $\mathrm{com} /$ broadtour/] 